\title{
¿Hoy te has levantado o te levantaste? Treatment of dialectal variation in the presentation of past tenses in L2 Spanish textbooks published in Spain
}

¿Hoy te has levantado o te levantaste? Tratamiento de la variación dialectal en la presentación de tiempos del pasado en manuales de español como L2 publicados en España

\author{
Abraham Hernández Cubo \\ University of Melbourne, \\ School of Languages and Linguistics
}

\begin{abstract}
This study analyses the recognition of dialectal variation in L2 Spanish textbooks published in Spain with regard to the approach to describe the use of two tenses that convey past meaning: pretérito indefinido and pretérito perfecto compuesto. This language feature has been traditionally regarded as one that differentiates between the varieties of Spanish spoken on each side of the Atlantic, thus allowing the study of the variety preferred by authors. The findings reveal that most textbooks tend to favour the local variety. This trend, however, has been changing steadily over the past years,

as progressively more textbooks acknowledge dialectal variations in the use of Spanish past tenses. The subjective nature of the semantic scopes of these two tenses and the fact that their deployment frequently depends on the choice of the speaker are largely neglected by most of the materials analysed. This research aims to raise awareness about the ideological nature of textbooks and the standard language ideologies often entrenched in them, while raising attention to dialectal diversity and language variation in second-language instruction.
\end{abstract}

Keywords: L2 Spanish textbooks; language variation; present perfect; preterite; standard language ideology 


\section{Resumen}

Este estudio analiza el reconocimiento de la variación dialectal en manuales para la enseñanza del español como lengua extranjera publicados en España, específicamente en relación con la manera en que presentan el uso de dos tiempos del pasado: el pretérito indefinido y el pretérito perfecto compuesto. Este rasgo ha sido tradicionalmente considerado como uno de los que distinguen las variedades del español en ambos lados del Atlántico, lo cual nos permite examinar qué variedad favorecen los autores. Los resultados muestran que la mayoría de los manuales favorecen la variedad local. Sin embargo, esta tendencia ha ido cambiando en los últimos años y los libros de texto van progresivamente reconociendo la variación dialectal en los usos de los tiempos del pasado. El carácter subjetivo del espectro semántico de estos dos tiempos y el hecho de que frecuentemente su uso dependa de la elección personal del hablante no son aspectos reconocidos por casi ninguno de los materiales analizados. Esta investigación pretende sensibilizar sobre la naturaleza ideológica de los libros de texto y las ideologías de estandarización lingüística imbuidas a menudo en ellos. También aspira a promover la atención a la diversidad dialectal y a la variación lingüística en la enseñanza de segundas lenguas.

Palabras clave: libros de texto de español como lengua extranjera (ELE); variación lingüística; pretérito perfecto compuesto; pretérito indefinido; ideología de estandarización lingüística 


\section{Introduction}

Students and teachers usually take the reliability of their pedagogic materials for granted (López García, 2010: 91; Meyer \& Rosenblatt, 1987: 247). We tend to assume the premise that, for example, in the field of language teaching, a textbook designed to teach Spanish does teach Spanish.

However, in order to unravel this tautology, we should ask ourselves what we understand by Spanish, a question that takes us to the more general enquiry of what we, language teachers, understand by language. Is language an enclosed system of rules and linguistic signs which we want our students to acquire, so that they can communicate in a different system from that of their mother tongues? Or is language an ever-changing, unstable interaction of diverse dimensions within a heterogenous open diasystem? Different frameworks have been proposed in an attempt to answer this question and comprehend the complexity of the language phenomenon. Coseriu (1981: 303) acknowledges language variation depending on the region, the social register, and the specific context. Multiplicity, the framework proposed by Nicholas and Starks (2014), conceives more dimensions and interconnecting threads to understand the communicative repertoire. In both cases, the diatopic level (in Coseriu's terms) or the macro-geopolitical element (in Nicholas and Starks's framework) reminds us of the importance of recognising regional diversity as a dimension to understand variation in language.

\subsection{Aim and scope of the study}

This study examines whether and how L2 Spanish textbooks published in Spain address dialectal variation in the presentation of their contents. It will focus on one language feature: the contrast in the semantics and frequency of occurrence between two of the tenses which convey past meaning: pretérito perfecto compuesto ${ }^{1}$ (hereafter abbreviated PPC) and pretérito indefinido ${ }^{2}$ (hereaftert referred to as PI). ${ }^{3}$

1 As in He visto esta película muchas veces [I have seen this movie many times]. All translations are mine, unless otherwise indicated.

2 As in Ayer vi una película maravillosa [Yesterday I watched a wonderful movie].

3 As I am analysing textbooks from Spain, I am using the terminology widely accepted in this 
The semantic domains of PPC and PI are regarded as features that occur differently in the Spanish varieties spoken in Spain (to which I will refer as the Peninsular variety) and in the Spanish-speaking countries of Latin America (hereafter comprised within the macro-geopolitical Hispanic American variety).

In her three-level classification of the characteristics that differentiate these two major varieties, Bravo García (2004: 195-196) includes the contraposition between PPC and PI in the first level, i.e., the category for generalised distinctive features which are not linguistically stigmatised. ${ }^{4}$ Among other language features that differentiate the Peninsular and Hispanic American varieties, the $\mathrm{PPC} / \mathrm{PI}$ contrast carries an additional point of interest. The decision to use one or the other is at times dependent on the subjectivity of the speaker (Harris, 1982: 54-55; Seco, 1998: 357). In these cases, we can dispute the rigidity of the rules used to teach these two tenses in the L2 Spanish classroom. This prompts us to question the extent to which the agency of learners to make their own choices is promoted or otherwise ignored by L2 Spanish textbooks.

Language textbooks are designed according to a range of factors, which may include "political decisions, educational beliefs and priorities, cultural realities and language policies" (Curdt-Christiansen \& Weninger, 2015: 1). External agents can therefore influence their contents. In the case of L2 Spanish materials, one such factor was the publication in 2006 of the Plan Curricular del Instituto Cervantes (hereafter PCIC). This master plan for curriculum design produced by the Instituto Cervantes proposed guidelines to design textbooks that, as will be illustrated by this research, were observed by many authors in Spain.

country to refer to these tenses (which is also the one followed by the materials of the corpus under study). However, I acknowledge that there are other terms to refer to these tenses. According to the Hispanic American terminology, Pretérito and Antepresente are common ways to refer to PI and PPC, respectively. English-speaking authors often use the names of the equivalent English tenses to refer to PI (simple past) and PPC (present perfect). However, as there is no univocal semantic equivalent between the Spanish tenses and their English counterparts, I have decided to use the original terms in Spanish.

4 The second level in Bravo García's typology refers to features that are functional mainly in the spoken register of a variety and reveal the specific regional origin of a written text. These may be colloquial, but usually not stigmatised. The third level refers to those features that are constrained to a very specific regional area and are either distinctly colloquial or stigmatised. 
This study will examine the potential influence of this document on how L2 Spanish textbooks address dialectal diversity in the presentation of the PPC/PI contrast.

Overall, this research contributes to raise awareness about the importance of the recognition of language variation in the L2 Spanish class and the acknowledgement of ideological stances embedded in textbook discourses. Neglecting linguistic diversity can affect the L2 Spanish classroom and entails a range of repercussions, from the construction of ethnocentric views in the mindsets of students and teachers (Cerdeira \& Ianni, 2009) to the perpetuation of traditionally sustained linguistic prejudices (López García, 2010; Showstack, 2012).

\section{The ideological dimension of textbooks}

Apple and Christian Smith (1991: 1) highlight that textbooks are ideological artifacts. This is somehow inevitable, given that their authors have, like anyone else, ideologies and beliefs that are likely to be conveyed in their works (Gazali, 2014: 49). Canale (2016: 226) argues that we should not consider authors as the sole agents of ideology in textbooks, as these are polyphonic products where the interventions of other people (publishers, editors, proofreaders, photographers, etc.) also have a relevant influence on the discourses embedded in the final output.

Students and teachers tend to rely on textbooks as a source of reputable factual knowledge and do not usually reflect on their ideological connotations (López García, 2010: 91; Meyer \& Rosenblatt, 1987: 247). Apple (1985: 153) emphasises that the producers of this "official knowledge" are people with specific characteristics and contexts, a circumstance that makes textbooks culturally mediated products, where the publishers' goal of gaining economic profit may play a crucial role. Standardisation or homogenisation allows publishers to target a wider market and avoid content modification in subsequent editions (Apple, 1985: 154; López García, 2010: 106).

Language textbooks are products of the ideological processes described above. This makes language learning and teaching ideological practices too, which will be influenced by the ideological nature of the textbooks used in class and their specific sociocultural paradigms (Curdt Christiansen \& Weninger, 2015: 1). The representations conveyed by these works can be assumed as the le- 
gitimate ones and contribute to the stigmatisation of the non-dominant representations (Curdt Christiansen \& Weninger, 2015: 3).

\section{Language ideology throughout the historical standardisation of Spanish}

\subsection{Definition of language ideology}

Silverstein, as cited by Woolard and Schieffelin (1994: 57), defines language ideologies as "sets of beliefs about language articulated by users as a rationalization or justification of perceived language structure and use". Alternatively, Rumsey (1990: 346) describes them as the "shared bodies of commonsense notions about the nature of language in the world".

For Woolard and Schieffelin (1994) these two approaches represent different perspectives to understand the notion of language ideology. On the one hand, it can be a rationalised view of the nature and usage of language; on the other, it can be an unconscious and culturally ingrained assumption (Woolard \& Schieffelin, 1994: 57-58). However, both positions state that language ideology is dependent on specific views of the world as well as on the social representations derived from them (Woolard \& Schieffelin, 1994: 58). The process by means of which an ideology is assumed by members of a linguistic community is an ideological process (Woolard \& Schieffelin, 1994: 58). As a result, these members perceive a specific stance as the default or true position to observe and judge a particular phenomenon.

\subsection{Standardisation as a language ideology}

Although, for practical reasons, foreign language instructors usually choose one variety to teach (generally theirs or, if the instruction is taking place in a Spanish-speaking country, the corresponding variety), their stance towards other dialects can influence how students perceive them. Beaven and Garrido (2000: 182) point out that both the selection of the regional variety that is supposed to be taught in the L2 Spanish classroom as well as the attitude towards this decision have an ideological component. Preference of one dialect over the others can be 
seen as an analogous process to the historical stigmatisation of certain varieties as either reputable or non-prestigious.

Since languages started to be recorded in written form, a need for standard codification was required to facilitate understanding among the members of a linguistic community (Paffey, 2012: 45). Milroy and Milroy (2012: 19) argue that, while this is a legitimate objective, this standardisation extended beyond the mere orthographic regulation and affected all levels of linguistic description, making it an ideological process that recognised some language features as correct, while regarding others as not prestigious enough to be incorporated to the standard. Haugen (1966: 931-933) distinguishes four stages within this standardisation process. Firstly, there is a (conscious or unconscious) selection of a vernacular as the potential standard. Secondly, the codification of that variety allows the linguistic description of that standard to be comprehensive. An elaboration stage will aim at promoting the maximum functionality of that variety among the speakers of the language. Finally, the acceptance of this vernacular as the standard by the members of a linguistic community enables it to be considered as the prestige variety. Standardisation naturalises the idea that one dialect is the model to which all speakers should aspire (Paffey, 2012: 47), even though, before this process takes place, this variety is just one of many in a particular language (Paffey, 2012: 46). Likewise, the speakers of the standard variety are seen as prestigious within the linguistic community, whereas the rest are othered for not being part of the chosen vernacular (Paffey, 2012: 47).

Standard language ideology has also played a role in the construction of national (and supranational) identities (Mar Molinero, 2000: 23; Paffey, 2012: 48; Woolard \& Schieffelin, 1994: 60-61). In the case of European languages, the role of continental institutions has been crucial in prescribing the standard varieties of these languages (Woolard \& Schieffelin, 1994: 64).

\subsection{A brief history of the standardisation of Spanish and its standardising agents}

\subsubsection{The Real Academia Española and the Peninsular variety}

The spread of the Spanish language throughout Spain's American Empire contributed to the creation of a vast Spanish-speaking community beyond the orig- 
inal birthplace of the language. Spanish was the language of power, administration, religion, and public life in the Americas and, therefore, inherently identified with the ruling elite (Mar Molinero, 2006: 15).

After the independence of the former Spanish colonies, Spain still assumed its role as the centre of Hispanism. By analysing the rhetoric of texts from Spanish Hispanists of the $19^{\text {th }}$ and $20^{\text {th }}$ centuries, Del Valle (2007: 247) concludes that even after the fall of the empire, a colonialist view of the language and its relation with the Spanish-speaking world endured. The Peninsular variety was considered as the prestigious one (Bugel \& Santos, 2010: 151; Del Valle, 2014: 360), a conception sustained by the regulating role of the Royal Spanish Academy of Language in Madrid (hereafter RAE, Spanish acronym for Real Academia Española), the institution that has prescribed the "correct" Spanish standard since its foundation in 1713 (Del Valle, 2007: 249).

\subsubsection{The shift to a Pan-Hispanic standard}

In the 19th century, other Spanish-speaking countries started to create language academies to promote their own policies, yet the Peninsular variety was still regarded as the prestigious vernacular by some philologists (Del Valle, 2014: 360). Even though in 1951 all language academies, including the RAE, founded the Association of Spanish Language Academies (ASALE, Spanish acronym for Asociación de Academias de la Lengua Española), it was not until the turn of the century that all of them started to effectively work together to describe the Pan-Hispanic variety of the language, i.e., the one shared by all Spanish speakers in the world (Del Valle, 2007: 249). This effort involved a shift in the attitude of the RAE, which modernised its image by stating that Spanish was a pluricentric language and that its role was no longer to establish the Peninsular variety as the model, but to work together with the other academies of the ASALE and adopt a Pan-Hispanic approach to describe the Spanish language in its varied nature (Del Valle, 2007: 252; Del Valle \& Villa, 2006: 373).

Del Valle (2007, 2014), along with Mar Molinero and Paffey (2011), highlight that despite the recent Pan-Hispanic attitude of the RAE, Spain still plays a dominant role in the design of language policies. By elaborating on Gramsci's concept of hegemony, Del Valle (2007: 258) states that the RAE's apparently in- 
clusive stance comes from its efforts to leave behind its prescriptive role, yet the way it chose to validate its discourse was not by imposing it on the other members of the ASALE, but by making this Pan-Hispanic approach appear as the natural position democratically chosen by all language academies.

Nonetheless, the extent to which the Spanish standard language ideology is intentional or unconscious in today's academic world is debatable. Álvarez De Miranda (2016), a RAE member, insists that this institution can only regulate the orthography and that the rest of the linguistic changes described in its academic publications merely reflect the natural choices of Spanish speakers. However, the fact that precisely these speakers still attribute the RAE a standardising role across all linguistic levels (Álvarez De Miranda, 2016; Marías, 2016) reveals the impact of the historical and influential prescribing tradition of this institution.

\subsubsection{The Instituto Cervantes and its Plan Curricular}

The Instituto Cervantes was created by the Spanish Ministry of Foreign Affairs in 1991 to promote the teaching of Spanish in the world and has become the leading voice in this field ever since (Del Valle, 2014: 363; Del Valle \& Villa, 2006: 373), mainly because of the proliferation of its branches across all continents.

In 2006, this institution published a master plan for curriculum design, the Plan Curricular del Instituto Cervantes (PCIC), a document that, by following the Common European Framework of Reference for Languages (CEFR), thoroughly describes the linguistic, functional, notional, pragmatic, and sociocultural components of each CEFR level in Spanish. The systematic, detailed, and comprehensive nature of this work has made it a reference for L2 Spanish curriculum designers and textbook authors (particularly in Spain).

Del Valle (2014: 363) maintains that the PCIC is hegemonic due to the Eurocentric nature of its section Norma lingüística y variedades del español [Linguistic norm and varieties of Spanish], where the Peninsular variety is favoured as the model on which the design of the whole document is based. Mar Molinero and Paffey (2011: 756) make similar assessments with regard to the variety chosen in the Aula virtual [Virtual classroom] of this institution. It should be noted that in the same section where the PCIC states its preference for the Peninsular dialect, it also affirms that the geographical diversification of Spanish is 
reflected in the description of each level (Instituto Cervantes, 2006a: 59). The extent and manner in which dialectal diversity is presented in the PCIC will be a starting point for this study.

\section{Pretérito Indefinido and Pretérito Perfecto Compuesto in Spanish}

\subsection{Synchronic description}

PI and PPC are two verb tenses of the indicative mood in contemporary Spanish. Morphologically, PI consists of a form that conveys person and number meaning through inflectional variation - canté [I sang] -, whereas PPC comprises a conjugated form of the present tense of haber and a participle - he cantado [I have sung] -. Semantically, they both express past tense and convey either a perfective aspect, where the action is signified as concluded (PI and also PPC, depending on the variety), or a perfect aspect where the action may or may not have finished but is seen by the speaker as somehow related to the current temporal context (mainly PPC) (Penny, 2002: 164).

Harris (1982: 54-55) and Seco (1998: 357) point out that this concept of present relevance can be subjective, as it depends on the kind of past actions each individual speaker considers to be connected with the present. Despite these blurry boundaries, the way these tenses occur in the Hispanic American and Peninsular varieties of contemporary Spanish differs significantly. In the latter, PI is mainly used when the time frame of the action is finished (e.g., La Segunda Guerra Mundial empezó en 19395), whereas PPC is preferred if the action happened during a period of time that is not considered to be concluded (e.g., No he visto a tu madre esta semana ${ }^{6}$ ) (Butt \& Benjamin, 2004: 226-228; Harris, 1982: 53; Howe \& Schwenter, 2003: 62-63). This pattern of use is relatively common and makes the occurrence of both tenses frequent in the Peninsular variety. However, this is not the case in some regions of Spain. Speakers from Galicia, Asturias, and the Canary Islands do not make the aforementioned dis-

5 World War Two began in 1939. [This text, like those in notes 6 and 7, are examples and translations taken from Butt \& Benjamin (2004), pages 210, 227 and 230, respectively].

6 I haven't seen your mother this week. 
tinction and use both tenses in relatively the same way as most of the speakers in the Hispanic American varieties (Berschin, 1976: 35; Butt \& Benjamin, 2004: 226, 227, 229; Harris, 1982: 53; Lapesa, 1981: 589).

In Hispanic America, PI has been traditionally considered as the preferred tense to convey past meaning, even if the time frame when the referred action took place is not concluded yet (e.g., Estudié mucho este mes ${ }^{7}$ ), which has led numerous studies to highlight that the use of PPC is far less frequent (Berschin, 1976: 35; Butt \& Benjamin, 2004: 226, 227, 230; Gutiérrez Araus, 1995: 26; Lapesa, 1981: 589-590; Moreno de Alba, 1988: 180). However, this affirmation overlooks the fact that referring to all Hispanic American varieties as a single entity represents a reductionist approach, given the dialectal diversity of the continent. The current uses of these two tenses in this area, especially in the spoken register, have not been analysed in greater depth, although there are sufficient studies to account for an obvious degree of variability within the semantic spectrum of the PPC/PI opposition. A similar distinction between PPC and PI to the one of the Peninsular variety can be found in regions of Peru, Bolivia, and northwest Argentina (Howe \& Schwenter, 2003: 61). Gutiérrez Araus and Montes, as cited by De La Torre García (2005: 300), include Lima and Bogota, respectively, in this list. Closer investigations on the uses of PPC and PI in Argentina and Peru have been conducted by Feliciano Duarte, Coan and De Oliveira Pontes (2016) and Jara Yupanqui $(2011,2013)$ respectively. A concise summary of the variation present in the uses of these tenses in Hispanic America is provided by Aleza Izquierdo and Enguita Utrilla (2010: 150). Although the absence of a homogenous semantic scope for the PPC/PI contrast in Hispanic America is evident, the interpretation by Feliciano Duarte, Coan and De Oliveira Pontes (2016: 97) on the conclusions by Aleza Izquierdo and Enguita Utrilla (2010: 150) summarise a widely accepted position towards their use: PPC is deployed by Hispanic American speakers, but the use of PI is predominant. Therefore, given the preponderance of the latter tense, this linguistic feature, in general terms, is deemed essential to differentiate the varieties spoken on both sides of the Atlantic.

7 I've done a lot of studying this month. 


\subsection{Diachronic evolution}

PI in Spanish is the evolved form of the perfect tense in Latin (cantāv $\bar{l})$, whereas PPC originated from the construction in spoken Latin habèo + cantātum (Penny, 2002: 165, 217). In some Romance languages the latter structure evolved to become the preferred form to signify past meaning in the spoken register, such as in French or Northern Italian, where the passé composé and the passato prossimo are nowadays the common structures to speak about past events, while the simple forms have been set aside for literary registers (Howe \& Schwenter, 2003: 61).

The aforementioned semantic development of the compound form has not evolved in Spanish in the same manner. In the early stages of the evolution of the language, the simple form was always preferred to convey past meaning (Alarcos Llorach, 1980: 39). Around the $13^{\text {th }}$ century, the compound construction overlapped the semantic scope of the simple form in order to express the perfective aspect of an action that had some effect in the present (Alarcos Llorach, 1980: 41; Penny, 1993: 159), but it was not until the end of the $16^{\text {th }}$ century that PPC started to be used in the Peninsular variety to refer to actions that had happened during a period of time relatively close to the present (Alarcos Llorach, 1980: 43). In the $17^{\text {th }}$ century, this new semantic domain of PPC in the vernacular of Spain became more stable (Alarcos Llorach, 1980: 43-44). Given that during this period Spanish had already started to spread around the Americas and that $16^{\text {th }}$ century Spanish is considered to be the basis from which the Hispanic American vernaculars developed (Moreno de Alba, 1988: 24), it is understandable that these varieties maintained the uses of PPC and PI as in the Peninsular variety before this linguistic shift became prevalent. Furthermore, it should be noted that this change did not manifest in the Canary Islands variety, which is believed to have influenced the linguistic configuration of the Hispanic American varieties, as the islands were a customary stopover in the route between the Spanish colonies and the metropole (Lapesa, 1981: 567).

As previously mentioned, some regions in Hispanic America are experiencing the same process by which PPC is replacing the semantic domain of PI, but this is not a generalised phenomenon in all varieties of the continent. At the same time, in Madrid, the distinction between PPC and PI is evolving even further, as the use of PPC has extended to contexts where the rest of Spanish speak- 
ers are expected to use PI, including to signify actions which occurred during a concluded period of time (e.g., Lo he visto ayer en el supermercado ${ }^{8}$ ) (Berschin, 1976: 35; Butt \& Benjamin, 2004: 226; Howe \& Schwenter, 2003: 64-65).

\section{Methodology}

\subsection{Research questions}

According to the objective of this study, the main research question is:

- To what extent and how is dialectal variation acknowledged by L2 Spanish materials from Spain when presenting the semantic contrast between PPC and PI?

This query is guided by other questions, such as:

- Which variety is chosen as the reference to introduce the uses of PPC and PI?

- Is the subjectivity of the speaker (and, by extension, that of the learner) presented as a possible factor in making choices regarding when to use PPC or PI?

- Do the PCIC guidelines influence the decisions made by textbook authors concerning the recognition of regional variation in the uses of PPC and PI?

\subsection{Corpus collection}

Under the concept of textbook, I refer to coursebooks intended for use in the L2 Spanish class. As the purpose of this research is to investigate whether and how the uses of two verb tenses are presented, materials such as readers, game books, etc. that do not address this feature are not being considered. Grammars and monographic studies on Spanish verbs are included as textbooks, but only if they were produced to teach Spanish as a foreign language (and provided this is stated on their covers or prefaces). Grammars aimed at linguists or designed as academic descriptions of the language were excluded. While there are also

8 I have seen him yesterday at the supermarket. Example extracted from Howe \& Schwenter (2003: 64) 
countless online materials, resources from the Internet have not been analysed to focus the scope of the research on print-based textbooks.

Thus, 162 books published in Spain from 1975 to 2014 were accessed for this study. Although different editions of the same materials were taken into consideration to analyse the evolution of potential standard language ideologies, the items of the corpus have been reduced to 114 to conduct the numerical analysis, considering that some of the textbooks were actually different volumes (i.e., different levels) of the same series. These were not considered as separate items, given that they are produced by the same publishing company and usually written by the same authors, or at least coordinated by the same pedagogic team.

Although there is usually consistency among different volumes of the same series, four of them presented the Peninsular contrast between PPC and PI in the beginners' levels texts to then address either the subjectivity of the speaker (Prisma) or dialectal differences of this opposition (Aula internacional, Método de español and Nuevo avance) in advanced levels. This approach could be seen as analogous to what Grande Alija (2000: 394) regards as a common tendency among L2 Spanish instructors: to delay the teaching of variation to later stages of the learning process - an approach consistent with the PCIC suggestions regarding when to introduce regional uses of the PPC/PI contrast, as I will examine in the next section.

\subsection{Analytical procedure}

After examining each textbook, several aspects were registered in an Excel data base. The information was organised as per the headings below:

- Title

- Year of publication

- Does it follow either the PCIC or the CEFR?

- Variety chosen to present the contrast between PPC and PI

- Are other varieties acknowledged?

- Is the subjectivity of the speaker acknowledged?

- Observations (remarks, quotes etc.) 
In order to attest the degree of dialectal recognition in the textbooks examined, a numerical summary of the findings seemed a suitable approach to report the analysis of the data. Consequently, the analysis began by looking at simple percentage differences related to four categories:

- The contrast between PPC and PI is presented through the Peninsular uses.

- The contrast between PPC and PI is presented through the Hispanic American uses.

- There is acknowledgement of regional variation in the uses of PPC and PI.

- There is acknowledgement of the subjectivity of the speaker in the uses of PPC and PI.

Because all variables are nominal, I have used a series of simple percentage comparisons for the analyses. In addition, the interpretation of the arguments provided by the textbooks is useful to evaluate potential assumptions embedded in these materials. Therefore, a qualitative examination of the contents is likewise essential to fully comprehend the scope of the research.

\section{Results of the analysis of the presentation of PPC and PI in the PCIC}

Since its publication in 2006, the PCIC became an important reference in Spain for L2 Spanish specialists, including textbook designers. It described the linguistic contents of each level of the CEFR and thus became a significant guide for textbook authors to sequence the content of their pedagogic materials. Given its relevance, it is important to analyse how the uses of PPC and PI are explained by this work.

In the grammatical description of the A2 level, the PCIC describes the uses of PPC and PI that students are supposed to learn at that stage (Instituto Cervantes, 2006a: 130-131). Regarding PI, it states that learners should know its basic meaning when referring to past actions that happened within a specific time frame (Instituto Cervantes, 2006a: 130-131), which is a universal use of this tense among all Spanish speakers (Butt \& Benjamin, 2004: 209-210).

The presentation of the uses of PPC is, nevertheless, different. It is advised that this tense be learnt in conjunction with temporal markers such as "hoy, este 
año, esta mañana" [today, this year, this morning] (Instituto Cervantes, 2006a: 130-131). The use of PPC to express past actions that happened during a still-ongoing period of time is characteristic of the Peninsular variety (Butt \& Benjamin, 2004: 226-228; Harris, 1982: 53; Howe \& Schwenter, 2003: 62-63). The decision to present the use of PPC in such a manner is consistent with the intention of the PCIC to select the Peninsular vernacular as the reference (Instituto Cervantes, 2006a: 59), an act regarded as hegemonic by Del Valle (2014: 363).

Nonetheless, the way dialectal variation is acknowledged in the presentation of other linguistic features in the PCIC clearly shows the recognition of Hispanic American dialects throughout this work. Examples are the descriptions of the morphology of subject pronouns and of the present tense at the A1 level (Instituto Cervantes, 2006a: 120, 129). In both cases, the PCIC recognises regional diversity in detail, an approach absent in the presentation of the uses of PPC at the A2 level. The dialectal variation of the PPC/PI contrast is only recognised when the grammar of the $\mathrm{C} 1$ level is outlined, where the PCIC states that PI is preferred over PPC by speakers in Hispanic America as well as in northern and southern regions of Spain (Instituto Cervantes, 2006b: 78). This involves a pedagogic implication, since the PCIC suggests that L2 Spanish students should first know how the past tense is used in the Peninsular variety and wait until they acquire an advanced level of the language $(\mathrm{C} 1)$ to learn that the majority of speakers differ in their use of PPC and PI. Interestingly, there is no reference to the uses of these tenses in those Hispanic American regions where PPC is deployed in a similar way as in the Peninsular variety.

The manner in which the semantic scope of both tenses is worded also deserves attention. Firstly, in the grammatical outline of the A2 level the use of PPC in the Peninsular variety is not identified as a regionalism, but as the "regla general" [general rule] (Instituto Cervantes, 2006a: 131). The fact that a linguistic phenomenon in a specific vernacular is generalised as the norm can be seen as a hegemonic position, especially if the dialect concerned (Peninsular) has traditionally been considered as the vernacular of prestige (Bugel \& Santos, 2010: 151; Del Valle, 2014: 360). The connotation of the word general is not used here to refer to the meaning assigned to PPC by the majority of Spanish speakers, but it appears to be used to standardise a linguistic use by resorting to its occurrence in a minority but traditionally prestigious variety. 
In the description of PPC at the $\mathrm{C} 1$ level, the Peninsular vernacular is once again seen as the reference from which the others diverge, as these varieties are said to use PI "en lugar de" [instead of] PPC (Instituto Cervantes, 2006b: 78). However, if we look at the diachronic development of these two tenses, the evolution has actually been the other way round, as PPC is the tense which has historically overlapped the original semantic spectrum of PI (Alarcos Llorach, 1980; Penny, 2002). The viewpoint of the PCIC is derived from a distinction between PPC and PI that regards the uses outside the Peninsular variety as deviations. This appears to be a linguistically ideological stance. Given the detailed references to dialectal diversity in the description of other grammatical phenomena in the PCIC, it is likely that this standardising ideology in the presentation of PPC and PI could be of an unintentional type, although this cannot be affirmed with certainty.

Because the Peninsular variety is selected as the reference, the grammatical points from this dialect are presented as unmarked in the examples just mentioned while the ones that deviate from the favoured vernacular are labelled according to the regions where they occur. As with the entries in the dictionary of the RAE, this approach can be seen as ideological because the unmarked information is identified with the standard or default choice, not with another region that deserves a geographical label in order to make its status equal to that of the ones marked as regionalisms (Paffey, 2012: 55; Stewart, 1999: 19).

\section{Results of the analysis of the presentation of PPC and PI in the textbooks}

The table below summarises the numbers of the four nominal features used in the analysis of the 114 texts. These are given as simple percentage differences:

TABLE 1. General overview of the four nominal features under study in the textbooks corpus

\begin{tabular}{lcc}
\hline \multicolumn{1}{c}{ Features } & $\begin{array}{c}\text { Number OF TeXtBooks } \\
\text { (114 ITEMS) }\end{array}$ & PeRcentage \\
\hline The contrast between PPC and Pl is presented through the Peninsular uses & 110 & 96.49 \\
The contrast between PPC and PI is presented through the Hispanic American uses & 4 & 3.50 \\
There is acknowledgement of regional variation in the uses of PPC and Pl & 29 & 25.43 \\
There is acknowledgement of the subjectivity of the speaker in the uses of PPC and Pl & 3 & 2.63 \\
\hline
\end{tabular}


The data showed that the majority of the L2 Spanish textbooks under investigation $(96.49 \%$ ) present the PPC/PI contrast through their Peninsular uses, i.e., by teaching that PPC is deployed by speakers of Spanish when they refer to past actions that happened in unconcluded time frames, such as hoy, este mes [today, this month]. Twenty-nine materials $(25.43 \%)$ recognise regional variation in this language feature and only three works $(2.63 \%)$ acknowledge the role of the subjectivity of the speaker.

Considering that the PCIC was published in 2006, and 2007 is the year in which some materials started to explicitly recognise its guidelines, 2007 has been chosen as the reference to categorise the corpus in pre- and post-PCIC publications. This allows us to assess whether there has been an evolution in the manner in which regional acknowledgement is presented, and whether the PCIC has influenced this evolution.

The table below shows how the 63 textbooks published before 2007 and the 51 published in and after 2007 address dialectal variation in the uses of PPC and PI:

TABLE 2. Pre- and post-PCIC dialectal representation in the textbooks corpus

\begin{tabular}{|c|c|c|c|c|}
\hline \multirow{2}{*}{ FEATURES } & \multicolumn{2}{|c|}{$\begin{array}{l}\text { PUBLISHED BEFORE } 2007 \\
\text { (63 ITEMS) }\end{array}$} & \multicolumn{2}{|c|}{$\begin{array}{l}\text { PUBLISHED IN AND AFTER } 2007 \\
\text { (51 ITEMS) }\end{array}$} \\
\hline & $\begin{array}{l}\text { Number of } \\
\text { textbooks }\end{array}$ & Percentage & $\begin{array}{l}\text { Number of } \\
\text { textbooks }\end{array}$ & Percentage \\
\hline $\begin{array}{l}\text { The contrast between PPC and PI is presented } \\
\text { through the Peninsular uses }\end{array}$ & 60 & 95.23 & 50 & 98.03 \\
\hline $\begin{array}{l}\text { The contrast between PPC and PI is presented } \\
\text { through the Hispanic American uses }\end{array}$ & 3 & 4.76 & 1 & 1.96 \\
\hline $\begin{array}{l}\text { There is acknowledgement of regional variation } \\
\text { in the uses of PPC and PI }\end{array}$ & 14 & 22.22 & 15 & 29.41 \\
\hline $\begin{array}{l}\text { There is acknowledgement of the subjectivity of } \\
\text { the speaker in the uses of PPC and PI }\end{array}$ & 2 & 3.17 & 1 & 1.96 \\
\hline
\end{tabular}

Within the sample of 63 books published before 2007, three (4.76\%) present the Hispanic American uses of PPC; however, as they do not label these as Hispanic American (nor do they label dialectal differences), we can infer that the authors of these textbooks may have chosen to present the uses of PPC shared by all Spanish speakers (rather than categorising them from a geographical perspective). 
Fourteen textbooks (22.22\%) do recognise regional diversity within the uses of PPC and PI. The number of materials that acknowledge the agency of the speaker (and consequently the learner) to decide the extent to which a past event is connected to the present is low, with only two works (3.17\%) addressing this topic.

In the textbooks published in and after 2007, there is a slight difference in the percentage of materials that address regional variation $(29.41 \%$ after 2007 , as opposed to $22.22 \%$ before 2007), which suggests that the more recent Spanish textbooks may be somewhat more sensitive to dialectal diversity than earlier ones. Only one textbook chooses the Hispanic American variety to present the uses of PPC and PI: Prisma latinoamericano. This work is an adaptation of the textbook Prisma to the Latin American variety and will be discussed in detail later. Seventeen textbooks (33.33\%) acknowledge the guidelines of the PCIC on their covers or prologues. Among the $34(66.66 \%)$ that do not include this recognition, 27 (52.94\%) observe at least the distinction of levels proposed by the CEFR. As the PCIC is the only published document that adapts the guidelines of the CEFR to the Spanish language, it is likely that some of these 27 materials might have also drawn on the linguistic description of the PCIC, although this circumstance cannot be attested if the PCIC is not explicitly acknowledged.

In order to assess the extent to which the guidelines of the PCIC might have influenced authors to neglect the recognition of dialectal variation when they present the PPC/PI contrast, I examined which of the textbooks published in or after 2007 first acknowledge its guidelines and what proportion of these address regional diversity when they introduce the two tenses. This information is summarised in Table 3.

This table shows that, among the 15 materials which recognise dialectal variation, six (40\%) are designed according to the recommendations of the PCIC. This demonstrates that $40 \%$ of these authors exert agency to diverge from the PCIC guidelines in order to acknowledge variation. Nevertheless, 11 of the 36 textbooks that do not address dialectal diversity also follow the PCIC. It seems, therefore, that there are more textbooks not recognising dialectal variation, thus following the PCIC guidelines (11) than the other way round (six). Whether this is due to the authors' abiding by these guidelines or to their being influenced by their own standard language ideologies is a question that cannot be answered in this study. However, it opens up further areas of research, such as investigating 
whether those other language features for which the PCIC provides detailed regional information are presented by textbooks in a more dialectally sensitive manner.

TABLE 3. Relation of textbooks that acknowledge the PCIC and its recognition of dialectal variation

\begin{tabular}{|c|c|c|c|c|}
\hline & \multicolumn{2}{|c|}{$\begin{array}{l}\text { DIALECTAL VARIATION RECOGNITION } \\
\text { (PPC/PI CONTRAST) (15 ITEMS) }\end{array}$} & \multicolumn{2}{|c|}{$\begin{array}{l}\text { NO DIALECTAL VARIATION RECOGNITION } \\
\text { (PPC/PI CONTRAST) (36 ITEMS) }\end{array}$} \\
\hline & $\begin{array}{l}\text { Number of } \\
\text { textbooks }\end{array}$ & Percentage & $\begin{array}{l}\text { Number of } \\
\text { textbooks }\end{array}$ & Percentage \\
\hline $\begin{array}{l}\text { Both PCIC and CEFR are ack- } \\
\text { nowledged }\end{array}$ & 6 & 40 & 11 & 30.55 \\
\hline $\begin{array}{l}\text { PCIC is not acknowledged, but } \\
\text { CEFR is }\end{array}$ & 7 & 46.66 & 20 & 55.55 \\
\hline $\begin{array}{l}\text { There is no acknowledgement } \\
\text { of either PCIC or CEFR }\end{array}$ & 2 & 13.33 & 5 & 13.88 \\
\hline
\end{tabular}

\subsection{The type of dialectal acknowledgement}

Many textbooks teach the contrast between PPC and PI in the Peninsular variety by providing students with temporal markers that trigger the use of one tense or the other. When neither the subjectivity of the speaker nor regional variation are mentioned, learners could potentially deduce that these are fixed structural rules, rather than mere descriptions of linguistic habits in the Peninsular dialect.

The acknowledgement of variation usually appears in the form of a footnote or a chart on a side of the page where the uses of PPC and PI are outlined. The explanation in Gente hoy 1 can serve as an example to illustrate this aspect: "El contraste entre perfecto/indefinido varía mucho según los países e incluso según las regiones. En Latinoamérica y en muchas zonas de España está mucho más extendido el uso del indefinido que el del perfecto"9 (Peris \& Sans Baulenas, 2013: 169). All references to dialectal diversity relate to Latin America and some of them also include references to the regions in Spain where the

9 The contrast between perfecto/indefinido varies significantly across countries and even regions. In Latin America and in many parts of Spain the use of indefinido is much more common than that of perfecto. 
Peninsular variety is not followed. The nature of these acknowledgements has two limitations: first, as De La Torre García (2005: 301) indicates, these explanations constitute generalisations of the semantic dimension of these tenses, as they seem to convey the idea that all uses of PPC are simply transferred to PI in Hispanic America. This could give the impression to learners that the occurrence of PPC is nearly non-existent in the Hispanic American varieties, which is not an accurate depiction of the spectrum of this tense either. Second, although the Spanish regions that do not follow the Peninsular variety are occasionally mentioned, none of the textbooks provides a detailed recognition of the Hispanic American varieties that coincide with the Peninsular dialect in the uses of PPC. As highlighted above (Aleza Izquierdo \& Enguita Utrilla, 2010: 150; Howe \& Schwenter, 2003: 67), the semantic scope of PPC is not homogenous in all Hispanic American dialects.

\subsection{Two opposite approaches: Practica tu español: Ios tiempos de pasado and Prisma}

Two materials have been chosen as examples of very different stances towards the recognition of dialectal variation and standard language ideology.

The textbook Practica tu español: los tiempos de pasado [Practice your Spanish: Past tenses], published in 2006 by Sociedad General Española de Librería, focuses on the explanation and practice of past tenses in Spanish. The Peninsular variety is the chosen standard and, as such, the contrast between PPC and PI is taught by presenting PPC as the tense to be used with temporal markers that refer to an unfinished period of time. This does not differ from other textbooks published in Spain, but this work includes a section that was not found in any other material of the corpus, entitled "Errores más frecuentes en el uso de los tiempos de pasado en indicativo" [Most frequent errors in the use of past tenses of the indicative mood] (Losana, 2006: 70). As its title suggests, this section illustrates "algunos de los errores más frecuentes que suelen cometer los estudiantes de español cuando utilizan los tiempos del pasado" [some of the most frequent errors that students of Spanish make when using past tenses] (Losana, 2006: 70). What Losana regards as errors are precisely the uses of PI in Hispanic America. The verb in the example "¿Viste la tele hoy?” [Did you watch TV 
today?] is crossed out and replaced by the Peninsular version of this utterance “HHas visto la tele hoy?” [Have you watched TV today?] (Losana, 2006: 70). The author does not ignore that the PPC/PI contrast is dependent on regional variation, as he reminds the reader that in Spanish-speaking America, Galicia, Asturias, and the Canary Islands, PI is preferred over PPC (Losana, 2006: 70). However, the fact that the uses of the past tense in these regions are labelled as "errors" constitutes the most extreme case of standard language ideology of the corpus and a very prescriptive approach to language pedagogy. No other textbook among the corpus presents the PPC/PI opposition in this manner.

Prisma, from the publishing company Edinumen, represents an example of the evolution in the acquisition of dialectal awareness. This publication is divided into six volumes, each corresponding to a level of the CEFR. The work also acknowledges the PCIC guidelines. In the 2007 edition, the contrast between PPC and PI is introduced as it occurs in the Peninsular variety and excludes any recognition of regional differences. This is also the case with Club prisma, the adaptation of this textbook for adolescent learners published in the same year. Therefore, it can be concluded that this work apparently does not diverge from the PCIC guidelines. It was interesting to see that its $\mathrm{C} 1$ level volume does not address the dialectal variation of the uses of PPC, as recommended by the PCIC, but states that the relationship of this tense with the present time is dependent on the subjectivity of the speaker (Arroyo, Casado, Fernández, Fernández, Gómez, Martí, Mayor, Menéndez, Nicolás, Oliva, Pareja, Romero, Vázquez \& Wingeyer, 2007: 36).

The latest edition of this series of textbooks, Nuevo prisma, published in 2012 and 2013, approaches this matter differently. The first past tense introduced in the A1 level is PI, as opposed to the 2007 edition, in which it was PPC. Whether the reason for this change in the sequencing of the content responds to first presenting the tense that is more extensively used in the Spanish-speaking world is not possible to affirm, but what is clear is that dialectal awareness is present from the introduction of PPC in the A2 level. Nuevo prisma: nivel A2 outlines PPC as it occurs in the Peninsular variety, but also states that PI is preferred instead in the north of Spain and in most Spanish-speaking countries of Latin America (Bueso \& Isa, 2013: 33). 
In 2011, Edinumen published Prisma latinoamericano, an adaptation of the 2007 edition, where the variety chosen as the standard is Hispanic American (the Mexican variety, to be more specific). All explanations and activities of the previous Peninsular version are adapted to this variety. The unit in the A1 volume of the Peninsular version where PPC was explained is now replaced by one containing the same activities, but where PI has replaced PPC. Prisma latinoamericano: continúa (A2) presents the Hispanic American uses of PPC. The verb paradigm does not include the form for vosotros (only used in Spain) and the terminology to refer to the past tenses follows the Hispanic American tradition (Pretérito and Antepresente for PI and PPC, respectively). This time, the Peninsular use of PPC appears as a footnote (Blanco et al., 2011: 69). In summary, this work is aimed at teaching the Hispanic American variety as the reference, but it is actually a textbook published in Spain. Whether there are economic reasons to target a wider market or simply a shift in the awareness to address the diversity of the Spanish language, editing a whole textbook to change the variety established as the standard is the most significant case of dialectal recognition in the corpus. In addition, this represents a step forward from previous Mercosur versions of other textbooks (such as Planet@, from the publishing company Edelsa), where the dialectal recognition reflected a positive sensitivity to the question, but still placed Hispanic American varieties at a lower level with respect to the Peninsular standard (Bravo García, 2004: 197-198).

\subsection{Aula latina vs. Prisma latinoamericano}

Edinumen and Edelsa are not the only Spanish publishing companies that adapted Peninsular materials to the Hispanic American market. The publisher Difusión also launched a textbook for students learning Spanish in Mexico (Aula latina).

Similarly to Prisma latinoamericano, Aula latina adapts the contents of its Peninsular predecessor to the Mexican context. Although some of the results of this adjustment are obvious (e.g., the cultural allusions to Mexico or the replacement of lexical fields), the traces of the Peninsular provenance are still perceptible (at least to a greater extent when compared with Prisma latinoamericano). The presentation of PPC is delayed to the A2 level of Aula latina, unlike 
the Peninsular version that introduces this tense in the A1 volume before PI. This rearrangement in the sequencing is similar to that of Prisma latinoamericano, but as opposed to the work by Edinumen, Aula latina does not present PPC in a very different manner from its Peninsular predecessor. The temporal markers common in Peninsular textbooks, such as hoy, esta mañana [today, this morning], etc., also appear in Aula latina (Arévalo et al., 2005: 45) and the verb paradigms include the forms for vosotros (absent in Hispanic America). There is no mention of regional variation either, which makes it a dialectally less sensitive material than Prisma latinoamericano and one where the PPC/PI contrast has not been fully adapted to the Hispanic American reality.

The fact that the edition of Aula latina accessed for this study is dated in 2004 for Aula latina 1 and 2005 for Aula latina 2 supports the hypothesis that dialectal awareness in materials published in Spain was less prominent in the past and has increased marginally in the past decade. Not only does Prisma latinoamericano, published in 2011, deviate more clearly from the Peninsular standard language ideology underpinning older works, but the pedagogic team in charge of the series of textbooks Aula has also developed a more explicit awareness towards the recognition of dialectal diversity in recent years. Even the later Peninsular versions of this textbook recognise the macro-geopolitical differences in the uses of PPC and PI with more detail than Aula latina does (Corpas, Garmendia, \& Soriano, 2013: 65).

\section{Discussion}

\subsection{Varieties selected as reference}

Deciding which variety to teach in the L2 Spanish class (and how to refer to the others) is a complex choice. It seems coherent and legitimate to choose one's own macro-geopolitical variety to write a textbook for the L2 Spanish classroom, as it is the most accessible dialect for the author. Therefore, it is not surprising that most of the L2 Spanish works published in Spain mainly follow the Peninsular dialect to explain the PPC/PI contrast, as this study shows. 


\subsection{Recognition of dialectal variation}

As a general assessment of my findings, it can be concluded that the L2 Spanish materials produced in Spain are progressively recognising regional diversity in the uses of PPC and PI. The materials from 2007 onwards demonstrate a slight increase in the extent of this dialectal acknowledgement compared to those published before that year. Nevertheless, this trend is not prevalent yet, and over two thirds of these materials still do not recognise dialectal variation of the $\mathrm{PPC} / \mathrm{PI}$ opposition.

The type of dialectal recognition in these works is usually in the form of a brief explanation and mainly addresses the dichotomy Peninsular/Hispanic American. If there are further specifications, it is usually to outline that in some regions of Spain the Peninsular uses of PPC and PI are not evident. The textbooks examined do not address, however, that there are regions in Hispanic America where the semantic spectra of PPC and PI match the ones in the Peninsular variety.

\subsection{Acknowledgement of the subjectivity of the speaker}

As discussed above, the choice between PPC and PI is not only subject to dialectal variation, but also dependent on one's own view on how a past event is connected with the present (Harris, 1982: 54-55; Seco, 1998: 357). This aspect has been neglected by most of the textbooks under study, a stance that consequently does not provide students with the possibility of exerting agency in their own idiolect (the one they are constructing in the second language) by not allowing them to make a subjective choice. If the boundaries between Hoy me levanté a las siete [Today I woke up at seven] and Hoy me he levantado a las siete [Today I have woken up at seven] are blurred and can occasionally be a matter of (inadvertent) preference among native speakers of some varieties of Spanish, sustaining a standard language ideology that deems one as more "correct" than the other does not reflect the actual linguistic reality of the contrast between these two tenses. The textbooks that present the Peninsular variety often imply the rule that temporal markers with the demonstrative determiner este/-a [this] trigger the use of PPC. Even if this applies to the general preference of the Peninsular variety, more explicit references to the subjectivity of the semantic 
scope of these tenses and the personal agency of the speaker to deploy them are advisable.

\subsection{The role of the PCIC}

The PCIC, the interpretation by the Instituto Cervantes of how the levels of the CEFR adapt to the Spanish language, appears to be a popular guide for textbook authors in Spain. Within the corpus of textbooks published in Spain in or after 2007, it was found that there are more works following the PCIC that do not acknowledge regional differences when presenting the uses of past tenses (11) than those that actually do (six). The PCIC does not recommend addressing this regional variation in the early stages of learning (Instituto Cervantes, 2006a: 130-131), but given that some of the textbooks do introduce it early on, it can be concluded that some textbook authors demonstrate a certain level of agency in assessing the PCIC guidelines and adopt their own judgements concerning how references to dialectal variation are to be addressed. However, considering the proportions outlined in Table 3, this is still not the approach taken by most authors following the PCIC.

\subsection{Limitations and areas for further study}

Altogether, the data analysis conducted in this study cannot be generalised to state that it provides a comprehensive picture on the whole question of dialectal acknowledgement in L2 Spanish textbooks published in Spain. This is mainly due to the fact that I have focused on a single language feature. This choice, however, constitutes an invitation to carry out further investigation and examine the extent to which the findings would be similar or different when analysing other language features. This will add to the conclusions expressed by this research as well as by other studies (García Fernández, 2010; López García, 2010; Sánchez Avendaño, 2004). My conclusions are consistent with those from earlier research in that they indicate that L2 Spanish materials are slowly becoming more dialectally aware (García Fernández, 2010: 101; Grande Alija, 2000: 400), but do not regard dialectal recognition as a priority and address this aspect in a heterogenous or sometimes inaccurate manner (De La Torre García, 2005: 301; 
García Fernández, 2010: 101; López García, 2010: 100-101, 103, 106; Sánchez Avendaño, 2004: 146-148).

This study does not aim to clarify the reasons why textbook authors do or do not recognise regional variation in their works. A reliable examination of this question would require an evaluation of the assumptions embedded in discourses that textbook authors could convey during interviews with researchers interested in this field of study. This can be an enlightening line of research in further studies.

Aula latina and Prisma latinoamericano are adaptations of Peninsular textbooks to Hispanic American varieties, an approach which serves to raise the level of dialectal awareness. Adaptations entail assessments of the characteristics of the prior work and, therefore, open up opportunities for reflection. It will be interesting to see whether the trend of adjusting textbooks from one variety to another will grow in the future and, if so, how their authors will react to standard language ideologies potentially conveyed in prior editions.

Ignorance or the perpetuation of prejudices from the past, consciously or unintentionally made, are adduced by Sánchez Avendaño (2004: 132) as possible causes for the absence of acknowledgement of regional diversity in textbooks. López García (2010: 106) adds the insecurity of teachers as a factor in the transmission of these stigmas. The reasons to explain how standard language ideologies may prevail over pluricentric perspectives are probably as complex as the phenomenon itself. Further research needs to keep suggesting answers to these questions and, above all, raise awareness against homogeneous representations of language.

While textbooks are manifestations of language ideologies, they are not the only components of the educational reality, and equal attention should be paid on studies that examine standard language ideologies, attitudes towards regional variation, language prejudices, and linguistic hegemony in teachers and students (Beaven \& Garrido, 2000; Bugel \& Santos, 2010; Liceras, Carballo \& Droege, 1994; Showstack, 2012) as well as in policy makers (Del Valle, 2014; Del Valle \& Villa, 2006).

If, in 2005, De La Torre García (2005: 296) already indicated how the recognition of Hispanic American varieties in textbooks from Spain was increasing through the years, this research confirms this trend (although not sufficiently ev- 
ident yet). Whether this trend will continue evolving is something that further research will need to clarify.

\subsection{Concluding remarks}

As discussed above, choosing which variety of a language to teach is a complex decision, where the specific context and needs of the learners are decision criteria (Grande Alija, 2000: 396). The selection of a specific dialect (and the lack of recognition of others) may address the needs of those students who want to immerse themselves in that particular variety (e.g., because they want to live in that specific country), but neglects the needs of L2 Spanish instruction in non-Spanish speaking countries, where students usually aim to gain a more global perspective. In either case, presenting the other varieties as "una rareza lingüística" [a linguistic rarity] (Bravo García, 2004: 197) should be avoided.

Nicholas and Starks (2014: 42) highlight how authors (not only of textbooks, but also of curricula or language policies) make choices and how these tend to delimit a model, even though there is not just one homogenous code. Likewise, teachers usually play down the importance of linguistic diversity to create rules in the classroom, neglecting to teach that the standard is affected by ambiguity and that languages are a product of the interaction of multiple features (Nicholas \& Starks, 2014: 42). This position is consistent with the questioning of language as a stable system, which McNamara (2012: 477) claims should be a guiding principle to guide investigation in Applied Linguistics.

This study aims at raising awareness to address the richness of regional variation in L2 Spanish materials in a more sensitive manner. Nonetheless, following the recommendation of Sánchez Avendaño (2004: 146) it does not suggest that Spanish textbooks should become detailed works on Spanish dialectology, as an overly detailed exposition about the many different forms of the same concept may indicate to students that learning Spanish requires a strenuous effort or that the macro-geopolitical varieties are confusingly different from each other. That should not be the aim of effective second language instruction. Further, Bravo García (2004: 198) reminds us that the varieties of Spanish are similar at their core and should be incorporated to the L2 Spanish class as a positive phenomenon that enriches the language. What is needed, and appears not 
to be openly embraced by many of the textbooks in this study, is a discussion about stances towards variation that allows this issue to be addressed. This research supports the position of Sánchez Avendaño (2004: 146) when he recommends that we should discontinue monolithic views on language that conceive only one particular form as the "correct" one. My research aims at promoting reflection and fostering awareness of standard language ideologies as a way to enhance sensitivity towards the pluricentric nature of second language instruction, a stance needed if we want to understand the world from an ethnorelative perspective.

\section{References}

Alarcos Llorach, Emilio (1980). Estudios de gramática funcional del español (3rd. ed.). Madrid: Gredos.

Aleza Izquierdo, Milagros, \& Enguita Utrilla, José María (Coords.) (2010). La lengua española en América: normas y usos actuales. Valencia: Universitat de València.

Álvarez De Miranda, Pedro (2016, 3 July). Dejad a la lengua en paz. El País. Retrieved from http://cultura.elpais.com/cultura/2016/06/30/actualidad/1467295497_943703.html

Apple, Michael W. (1985). The culture and commerce of the textbook. Journal of Curriculum Studies, 17(2), 147-162. doi: 10.1080/0022027850170204

Apple, Michael W., \& Christian Smith, Linda K. (1991). The politics of the textbook. In Michael W. Apple \& Linda K. Christian Smith (Eds.), The politics of the textbook (pp. 1-21). London: Routledge.

Beaven, Tita, \& Garrido, Cecilia (2000). El español tuyo, el mío, el de aquél... ¿Cuál para nuestros estudiantes? In María Antonia Martín Zorraquino \& Cristina Díez Pelegrín (Eds.), ¿Qué español enseñar? Norma y variación lingüísticas en la enseñanza de español a extranjeros. Actas del XI Congreso Internacional de ASELE (pp. 181-190). Zaragoza: Universidad de Zaragoza.

Berschin, Helmut (1976). Präteritum- und Perfektgebrauch im heutigen Spanisch. Tübingen: Max Niemeyer Verlag.

Bravo García, Eva (2004). La variedad americana en la enseñanza del español como L2. In María Auxiliadora Castillo Carballo, Olga Cruz Moya, Juan Manuel García Platero \& Juan Pablo Mora Gutiérrez (Coords.), Las gramáticas y los diccionarios en la enseñanza del español como segunda lengua: deseo y realidad. Actas del XV Congreso Internacional de ASELE (pp. 193-198). Sevilla: Universidad de Sevilla. 
Bugel, Talia, \& Santos, Hélade Scutti (2010). Attitudes and representations of Spanish and the spread of the language industries in Brazil. Language Policy, 9(2), 143-170. doi: 10.1007/ s10993-010-9166-3

Butt, John, \& Benjamin, CARMen (2004). A new reference grammar of modern Spanish (4th. ed.). London: Hodder Education.

Canale, Germán (2016). (Re)Searching culture in foreign language textbooks, or the politics of hide and seek. Language, Culture and Curriculum, 29(2), 225-243. doi: 10.1080/07908318.2016.1144764

Cerdeira Núñez, Paula, \& Ianni, José Vicente (2009). Etnocentrismo y variedades dialectales en el aula E/LE. In Agustín Barrientos Clavero, José Carlos Martín Camacho, Virginia Delgado Polo \& María Inmaculada Fernández Barjola (Eds.), El profesor de español LE/L2. Actas del XIX Congreso Internacional de la Asociación para la Enseñanza del Español como Lengua Extranjera (ASELE) (Vol. 1, pp. 363-370). Cáceres: Universidad de Extremadura.

Coseriu, Eugenio (1981). Lecciones de lingüística general. Madrid: Gredos.

Curdt Christiansen, Xiao Lan, \& Weninger, Csilla (2015). Ideology and the politics of language textbooks. In Xiao Lan Curdt Christiansen \& Csilla Weninger (Eds.), Language, ideology and education: The politics of textbooks in language education (pp. 1-8). London: Routledge.

De La Torre García, Mercedes (2005). Sobre algunos aspectos de la gramática del español de América en los manuales de español para extranjeros. In María Auxiliadora Castillo Carballo, Olga Cruz Moya, Juan Manuel García Platero, \& Juan Pablo Mora Gutiérrez (Eds.), Las gramáticas y los diccionarios en la enseñanza del español como segunda lengua: deseo y realidad. Actas del XV congreso internacional de ASELE (pp. 296-302). Sevilla: Universidad de Sevilla.

Del VAlle, José (2007). Embracing diversity for the sake of unity: Linguistic hegemony and the pursuit of total Spanish. In Alexandre Duchêne \& Monica Heller (Eds.), Discourses of endangerment: Ideology and interest in the defence of language (pp. 242-267). London: Continuum.

Del Valle, José (2014). The politics of normativity and globalization: Which Spanish in the classroom? Modern Language Journal, 98(1), 358-372. doi: 10.1111/j.1540-4781.2014.12066.x

Del Valle, José, \& Villa, Laura (2006). Spanish in Brazil: Language policy, business, and cultural propaganda. Language Policy, 5(4), 371-394. doi: 10.1007/s10993-006-9035-2

Feliciano Duarte, Denísia Kênia; Coan, Márluce, \& De Oliveira Pontes, Valdecy (2016). A variação entre o pretérito perfeito simples e o pretérito perfeito composto no espanhol ar- 
gentino. Signo y Seña, 30, 91-107. Retrieved from https://dialnet.unirioja.es/servlet/articulo?codigo $=6482721$

García Fernández, Enrique (2010). El tratamiento de las variedades de español en los manuales de L2/ELE. (Master's thesis). Universidad Nacional de Educación a Distancia, Madrid.

Gazali, Andrea Rosana (2014). Un abordaje de los procedimientos en relación con los contenidos de lengua y cultura en tres manuales de enseñanza de español como lengua extranjera (ELE). Anales de Lingüística, 1, 47-77.

Grande Alija, Francisco Javier (2000). La diversidad del español a través de los manuales de E/LE. ¿Qué lengua enseñan? In María Antonia Martín Zorraquino \& Cristina Díez Pelegrín (Eds.), ¿Qué español enseñar? Norma y variación lingüísticas en la enseñanza de español a extranjeros. Actas del XI Congreso Internacional de ASELE (pp. 393-402). Zaragoza: Universidad de Zaragoza.

Gutiérrez Araus, María Luz (1995). Formas temporales del pasado en indicativo. Madrid: Arco Libros.

HARRIs, MARTIN (1982). The 'past simple' and the 'present perfect' in Romance. In Nigel Vincent, Martin Harris \& Joe Cremona (Eds.), Studies in the Romance verb: Essays offered to Joe Cremona on the occasion of his 60th birthday (pp. 42-70). London: Croom Helm.

Haugen, Einar (1966). Dialect, language, nation. American Anthropologist, 68(4), 922-935.

Howe, Chad, \& Schwenter, Scott A. (2003). Present perfect for preterite across Spanish dialects. University of Pennsylvania Working Papers in Linguistics, 9(2), 61-75.

Instituto Cervantes (2006a). Plan curricular del Instituto Cervantes: niveles de referencia para el español: A1-A2. Madrid: Biblioteca Nueva.

Instituto Cervantes (2006b). Plan curricular del Instituto Cervantes: niveles de referencia para el español: C1-C2. Madrid: Biblioteca Nueva.

Jara Yupanqui, Margarita (2011). Present perfect usage in Peruvian Spanish and perfective readings in narratives. Revista Internacional de Lingüística Iberoamericana, 9(18), 213-235. Retrieved from https://www.jstor.org/stable/41678478

Jara YuPanqui, Margarita (2013). El perfecto en el español de Lima: variación y cambio en situación de contacto lingüístico. Lima: Pontificia Universidad Católica del Perú.

Lapesa, Rafael (1981). Historia de la lengua española (9th. ed.). Madrid: Gredos.

Liceras, Juana M.; Carballo, Alicia, \& Droege, Sonja (1994). El tema de las variedades del español en los programas del español como lengua extranjera. Revista de Filología Románica, 11-12, 291-308. 
López García, María Pilar (2010). Norma estándar, variedad lingüística y español transnacional: ¿la lengua materna es la lengua de la "madre patria”? Revista de Lingüística y Lenguas Aplicadas, 5, 89-108. doi: 10.4995/rlyla.2010.755.

Mar Molinero, Clare (2000). The politics of language in the Spanish-speaking world: From colonisation to globalisation. London: Routledge.

Mar Molinero, Clare (2006). Forces of globalization in the Spanish-speaking world: Linguistic imperialism or grassroots adaptation. In Clare Mar Molinero \& Miranda Stewart (Eds.), Globalization and language in the Spanish-speaking world: Macro and micro perspectives (pp. 8-26). Basingstoke: Palgrave Macmillan.

Mar Molinero, Clare, \& Paffey, Darren (2011). Linguistic imperialism: Who owns global Spanish? In Manuel Díaz Campos (Ed.), The handbook of Hispanic sociolinguistics (pp. 747764). Hoboken: Wiley-Blackwell.

Marías, Javier (2016, 5 June). Narcisismo hasta la enfermedad. El País Semanal. Retrieved from http://elpaissemanal.elpais.com/columna/narcisismo-enfermedad/

McNamara, Tim (2012). Poststructuralism and its challenges for Applied Linguistics. Applied Linguistics, 33(5), 473-482. doi: 10.1093/applin/ams055

Meyer, Cynthia, \& Rosenblatt, Paul (1987). Feminist analysis of family textbooks. Journal of Family Issues, 8(2), 247-252.

Milroy, James, \& Milroy, Lesley (2012). Authority in language: Investigating standard English. London: Routledge.

Moreno de Alba, José G. (1988). El español en América. México: Fondo de Cultura Económica.

Nicholas, Howard, \& Starks, Donna (2014). Language education and applied linguistics: Bridging the two fields. London: Routledge.

PAFFEY, DARren (2012). Language ideologies and the globalization of 'standard' Spanish. London: Bloomsbury Academic.

Penny, Ralph J. (1993). Gramática histórica del español. Barcelona: Ariel.

Penny, RalPh J. (2002). A history of the Spanish language (2nd. ed.). New York: Cambridge University Press.

Rumsey, Alan (1990). Wording, meaning, and linguistic ideology. American Anthropologist, 92(2), 346-361.

Sánchez Avendaño, Carlos (2004). Variación morfosintáctica y enseñanza del español como lengua extranjera: reflexiones de un lingüista metido a profesor. Revista de Filología y Lingüística de la Universidad de Costa Rica, 30(2), 131-154. Retrieved from http://revistas.ucr. ac.cr/index.php/filyling/article/view/4442 
Seco, Manuel (1998). Diccionario de dudas y dificultades de la lengua española (10th. ed.). Madrid: Espasa Calpe.

Showstack, Rachel Elizabeth (2012). Symbolic power in the heritage language classroom: How Spanish heritage speakers sustain and resist hegemonic discourses on language and cultural diversity. Spanish in Context, 9(1), 1-26. doi:10.1075/sic.9.1.01sho

Stewart, Miranda (1999). The Spanish language today. London: Routledge.

Woolard, Kathryn A., \& Schieffelin, Bambi B. (1994). Language ideology. Annual Review of Anthropology, 23, 55-82. doi:10.1146/annurev.an.23.100194.000415

\section{Corpus of textbooks}

Alcoba, Santiago; Gómez Asencio, José Jesús, \& Borrego Nieto, Julio (2002). Es español 1: nivel inicial. Madrid: Espasa Calpe.

Alonso Cuenca, Montserrat, \& Prieto Prieto, Rocío (2011). Embarque 2: curso de español lengua extranjera: libro del alumno. Madrid: Edelsa.

Alonso Raya, Rosario; Castañeda Castro, Alejandro; Martínez Gila, Pablo; Miquel López, Lourdes; Ortega Olivares, Jenaro, \& Ruiz Campillo, José Plácido (2013). Gramática básica del estudiante de español. Barcelona: Difusión.

Alonso, Encina, \& González, Cristóbal (2014). Gramática práctica de español para jóvenes: nivel básico. Madrid: Sociedad General Española de Librería.

Alonso, Encina; Martínez Sallés, Matilde, \& Sans, Neus (2005). Gente joven 2. Barcelona: Difusión.

Álvarez Martínez, María Ángeles; Blanco Canales, Ana; Gómez Sacristán, María LuiSA, \& PÉrez De la CRUz, Nuria (2005). Sueña 1: nivel inicial. Madrid: Anaya/Universidad de Alcalá.

Álvarez Martínez, María Ángeles; Alarcón Pérez, Clara; Blanco Canales, Ana, \& TorRens Álvarez, María Jesús (2005a). Vuela 2: A1. Madrid: Anaya/Universidad de Alcalá.

Álvarez Martínez, María Ángeles; Alarcón Pérez, Clara; Blanco Canales, Ana, \& Torrens Álvarez, María Jesús (2005b). Vuela 3: A2. Madrid: Anaya/Universidad de Alcalá.

Álvarez Martínez, María Ángeles; Alarcón Pérez, Clara; Blanco Canales, Ana, \& Torrens Álvarez, María Jesús (2010a). Curso intensivo A1. Madrid: Anaya/Universidad de Alcalá. 
Álvarez Martínez, María Ángeles; Alarcón Pérez, Clara; Blanco Canales, Ana, \& ToRrens Álvarez, María Jesús (2010b). Curso Intensivo A2. Madrid: Anaya/Universidad de Alcalá.

Álvarez Martínez, María Ángeles; De La Fuente Martínez, María Vega; Giraldo Silverio, Inocencio; Martín Martín, Fátima; Sanz Sánchez, Begoña, \& Torrens Álvarez, MARÍA Jesús (2003). Sueña 3. Español lengua extranjera. Nivel avanzado. Libro del alumno. Madrid: Anaya/Universidad de Alcalá.

Álvarez Ramos, Damaris; Catalán Gallén, Susana; Giner Guix, Susana; González Argüello, Vicenta; López Samaniego, Ana; Martínez Díaz, Eva; Miñano López, Julia; Polanco Martínez, Fernando, \& Velázquez Velázquez, Raquel (2008). Destino Erasmus 2: guía didáctica. Madrid: Sociedad General Española de Librería/Universitat de Barcelona.

Aragonés, Luis, \& Palencia, Ramón (2009a). Gramática de uso del español: teoría y práctica: A1-A2. Madrid: Ediciones SM.

Aragonés, Luis, \& Palencia, Ramón (2009b). Gramática de uso del español: teoría y práctica: B1-B2. Madrid: Ediciones SM.

Aragonés, Luis, \& Palencia, Ramón (2010). Gramática de uso del español: teoría y práctica: A1-B2. Madrid: Ediciones SM.

Arévalo, María Elena; Bautista, Edith; Corpas, Jaime; García, Eva; Jiménez, Helena, \& Garmendia, Agustín (2004). Aula latina 1: curso de español. Barcelona: Difusión/Centro de Investigación y Publicaciones de Idiomas.

Arévalo, María Elena; Bautista, Edith; Corpas, Jaime; Garmendia, Agustín; Jiménez, HeLEna, \& Soriano, CARMen (2005). Aula latina 2: curso de español. Barcelona: Difusión.

Arrarte, Gerardo (2007). ¡Adelante! Método de español para estudiantes extranjeros de enseñanza secundaria. Madrid: Edinumen.

Arroyo, Margarita; Casado, María Ángeles; Fernández, Esther; Fernández, Zara; Gómez, Raquel; Martí, Manuel; Mayor, Iván; Menéndez, Mar; Nicolás, Silvia; Oliva, Carlos; Pareja, María José; Romero, Ana María; Vázquez, Ruth, \& Wingeyer, Hugo (2007). Prisma: método de español para extranjeros: consolida: nivel C1. Madrid: Edinumen. Artuñedo, Belén, \& Donson, Cynthia (2001). ele 2: curso de español. Madrid: Ediciones Sm. Ballester Bielsa, Pilar; Catalán Gallén, Susana; Díaz Tapia, María Ángeles; lópez Ripoll, Silvia; López Samaniego, Ana, \& Miñano López, Julia (2009). Destino Erasmus 1. Madrid: Sociedad General Española de Librería/Universitat de Barcelona.

BARros, Esther (2003). Dificultades del español para hablantes de alemán. Madrid: Ediciones SM. 
Blanco Canales, Ana; Fernández López, María Carmen, \& Torrens Álvarez, María Jesús (2005). Sueña 4. Madrid: Anaya/Universidad de Alcalá.

Blanco, Raquel; Gómez, Raquel; Nicolás, Silvia; Oliva, Carlos; Reig, Marisa; Ruiz de Gauna, María; VázQuez, Ruth; Reyes, Elizabeth; Cárdenas, María de las mercedes; Dávila, Rosa Estela, \& Navarro, Luis (2011). Prisma Latinoamericano: método de español para extranjeros: continúa: nivel A2. Madrid: Edinumen.

Blanco, Raquel; Gómez, Raquel, Nicolás, Silvia; Oliva, Carlos; Ruiz de Gauna, María, \& VÁzQuez, Ruth (2007). Prisma: método de español para extranjeros: continúa: nivel A2. Madrid: Edinumen.

Bodas, Milagros; De Pedro, Sonia; lópez Barberá, Isabel; Bartolomé Alonso, María Paz; Alzugaray Zaragüeta, Pilar, \& Blanco Gadañón, Ana Isabel (2006). Mañana 2 (2nd. ed.). Madrid: Anaya.

Borobio, Virgilio (1995). ele 1: curso de español para extranjeros. Madrid: Ediciones SM.

Borobio, Virgilio (2007). Nuevo ELE inicial 2. Madrid: Ediciones SM.

Borobio, Virgilio (2011). ele actual A2. Madrid: Ediciones SM.

Borobio, Virgilio, \& Palencia, Ramón (2009). Nuevo ele intermedio. Madrid: Ediciones Sm.

Borrego Nieto, Julio; García Santos, Juan Felipe; Gómez Asencio, José, \& Prieto de los Mozos, Emilio (1993). Viaje al español 2: versión internacional. Madrid: Santillana.

Brennan, Brian, \& SÁnchez, Daniel (2013). De tú a tú: español para clases privadas. Barcelona: Difusión.

Bueso, Isabel, \& Casamián, Pilar (2001). Diferencias de usos gramaticales entre el español y el inglés. Madrid: Edinumen.

Bueso, IsABel, \& Isa, David (2013). Nuevo prisma: curso de español para extranjeros: nivel A2. Madrid: Edinumen.

Bueso, IsAbel, \& VÁzQuez, Ruth (2005). Gramática básica del español con ejercicios. Madrid: Edinumen.

Bueso, Isabel; Cerdeira, Paula; Gelabert, María José; Gómez, Raquel; Menéndez, Mar; Oliva, Carlos; Pardo, Isabel; Romero, Ana; Ruiz de Gauna, María, \& Vázquez, Ruth (2007). Club Prisma: método de español para jóvenes: elemental: nivel A2. Madrid: Edinumen.

Bueso, Isabel; Gómez, Raquel; Oliva, Carlos; Pardo, Isabel; Ruiz de Gauna, María, \& VÁzQuez, Ruth (2007). Prisma: método de español para extranjeros: comienza: nivel Al. Madrid: Edinumen. 
Bueso, Isabel; Gómez, Raquel; Oliva, Carlos; Pardo, Isabel; Ruiz de Gauna, María; VázQuez, Ruth; Reyes, Elizabeth; Cárdenas, María de las Mercedes; Dávila, Rosa Estela; Navarro, Luis, \& Martínez, Martha M. (2011). Prisma latinoamericano: método de español para extranjeros: comienza: nivel A1. Madrid: Edinumen.

Bueso, Isabel; Moreno, Nina; Vázquez, Ruth, \& Wingeyer, Hugo (2007). Diferencias de usos gramaticales entre español peninsular y español de América. Madrid: Edinumen.

Buitrago, Alberto; Díez, María Carmen; Domínguez, Rosario; Martín, Escolástico; Martín, María Soledad, \& Natal, María Elena (2007). Español lengua viva 2. Madrid: Santillana/Universidad de Salamanca.

Cabrerizo Ruiz, María Aránzazu; Gómez Sacristán, María Luisa, \& Ruiz Martínez, Ana MARÍA (2005). Sueña 2. Madrid: Anaya/Universidad de Alcalá.

Cáceres Lorenzo, María Teresa (2002). La conjugación verbal. Madrid: Anaya.

Calzado, Araceli (2006). Gramática esencial con el español que se habla hoy en España y en América Latina. Madrid: Ediciones SM.

Cárdenas Bernal, Francisca; Hierro Montosa, Antonio, \& Robles Ávila, Sara. (2012). Método de español 1. Madrid: Anaya.

Castro Viúdez, Francisca (2007). Aprende gramática y vocabulario 4. Madrid: Sociedad General Española de Librería.

Castro Viúdez, Francisca, \& Díaz Ballesteros, Pilar (2006). Aprende gramática y vocabulario 2. Madrid: Sociedad General Española de Librería.

Castro Viúdez, Francisca, \& Díaz Ballesteros, Pilar (2010). Aprende gramática y vocabulario 3. Madrid: Sociedad General Española de Librería.

Castro Viúdez, Francisca; Marín Arrese, Fernando, \& Morales Gálvez, Reyes (2004). Nuevo Ven 2. Madrid: Edelsa.

Castro Viúdez, Francisca; Marín Arrese, Fernando; Morales Gálvez, Reyes, \& Rosa MuÑoz, Soledad (1991). Ven 1. Madrid: Edinumen.

Castro Viúdez, Francisca; Marín Arrese, Fernando; Morales Gálvez, Reyes, \& Rosa Muñoz, Soledad (1994). Ven 2. Madrid: Edelsa.

Castro Viúdez, Francisca; Marín Arrese, Fernando; Morales Gálvez, Reyes, \& Rosa Muñoz, Soledad (2003). Nuevo Ven 1. Madrid: Edelsa.

Castro Viúdez, Francisca; Rodero Díez, Ignacio, \& Sardinero Franco, Carmen (2006a). Español en marcha 2 (2nd. ed.). Madrid: Sociedad General Española de Librería.

Castro Viúdez, Francisca; Rodero Díez, Ignacio, \& Sardinero Franco, Carmen (2006b). Español en marcha 3. Madrid: Sociedad General Española de Librería. 
Castro Viúdez, Francisca; Rodero Díez, Ignacio, \& Sardinero Franco, Carmen (2008a). Compañeros 1. Madrid: Sociedad General Española de Librería.

Castro Viúdez, Francisca; Rodero Díez, Ignacio, \& Sardinero Franco, Carmen (2008b). Compañeros 2. Madrid: Sociedad General Española de Librería.

Castro Viúdez, Francisca; Rodero Díez, Ignacio, \& Sardinero Franco, Carmen (2009). Compañeros 3. Madrid: Sociedad General Española de Librería.

Castro Viúdez, Francisca; Rodero Díez, Ignacio, \& Sardinero Franco, Carmen (2010). Compañeros 4. Madrid: Sociedad General Española de Librería.

Cerdeira, Paula, \& IAnni, José Vicente (2012). Nuevo prisma: curso de español para extranjeros: nivel A1. Madrid: Edinumen.

Cerrolaza Aragón, Matilde; Cerrolaza Gili, Óscar, \& Llovet Barquero, Begoña (1998a).Planet@ 1: libro de referencia gramatical: fichas y ejercicios. Madrid: Edelsa.

Cerrolaza Aragón, Matilde; Cerrolaza Gili, Óscar, \& Llovet Barquero, Begoña (1998b).Planet@ 1: versión Mercosur. Madrid: Edelsa.

Cerrolaza Aragón, Matilde; Cerrolaza Gili, Óscar, \& Llovet Barquero, Begoña (2000). Planet@ 3: libro de referencia gramatical: fichas y ejercicios. Madrid: Edelsa.

Cerrolaza Aragón, Matilde; Cerrolaza Gili, Óscar, \& Llovet Barquero, Begoña (2008). Pasaporte: nivel 2 (A2). Madrid: Edelsa.

Cerrolaza Gili, Óscar (2005). Diccionario práctico de gramática. Madrid: Edelsa.

Chamorro Guerrero, María Dolores; Lozano López, Gracia; Martínez Gila, Pablo; Muñoz Álvarez, Beatriz; Rosales Varo, Francisco; Ruiz Campillo, José Plácido, \& Ruiz FAJARdo, GuAdalupe (1995). Abanico: curso avanzado de español lengua extranjera. Barcelona: Difusión.

Conejo, Emilia, \& Tonnelier, Bibiana (2008). Cuadernos de gramática española: A1. Barcelona: Difusión.

Coronado González, María Luisa; García González, Javier, \& ZarZalejos Alonso, AleJANDRO R. (2009). Materia prima: curso de gramática (5th. ed.). Madrid: Sociedad General Española de Librería.

Corpas, Jaime; García, Eva, \& Garmendia, Agustín (2013). Aula internacional 1: curso de español: nueva edición. Barcelona: Difusión.

Corpas, Jaime; García, Eva; Garmendia, Agustín, \& Soriano, Carmen (2005). Aula internacional 1: curso de español. Barcelona: Difusión.

Corpas, Jaime; Garmendia, Agustín, \& Soriano, Carmen (2003). Aula 2: curso de español. Barcelona: Difusión. 
Corpas, Jaime; Garmendia, Agustín, \& Soriano, Carmen (2005). Aula internacional 2: curso de español. Barcelona: Difusión.

Corpas, Jaime; Garmendia, Agustín, \& Soriano, Carmen (2006). Aula internacional 3: curso de español. Barcelona: Difusión.

Corpas, Jaime; Garmendia, Agustín, \& Soriano, Carmen (2013). Aula internacional 2: curso de español: nueva edición. Barcelona: Difusión.

Corpas, Jaime; Garmendia, Agustín; Sánchez, Nuria, \& Soriano, Carmen (2014). Aula internacional 4: curso de español. Barcelona: Difusión.

Cuadrado, Charo; Melero, Pilar, \& Sacristán, Enrique (2009). Protagonistas. Madrid: Ediciones SM.

De Dios Martín, Anabel, \& Eusebio Hermira, Sonia (2009). Etapas Plus: nivel A2.1. Madrid: Edinumen.

Domínguez, Pablo, \& Bazo, Plácido (1994). Claves del español: gramática práctica. Madrid: Santillana.

Esteba Ramos, Diana; Peláez Santamaría, Salvador, \& Zayas López, Purificación (2012). Método de español 2. Madrid: Anaya

Eusebio, Sonia; Fernández, Carmen; Fernández, Zara, \& Sarralde, Berta (1999). Escala: español para extranjeros: nivel inicial-intermedio. Madrid: Edinumen.

Fente, Rafael, \& Wulff Alonso, Enrique (1991). Órbita 1. Madrid: Sociedad General Española de Librería.

Fente, Rafael; Siles, José, \& Wulff Alonso, Enrique (1989). ¿Qué tal, amigos? Madrid: Sociedad General Española de Librería.

Fernández, Jesús; Fente, RAfael, \& Siles, José (2006). Curso intensivo de español: gramática. Madrid: Sociedad General Española de Librería.

Fernández AgüERo, María (2007). Español para hablantes de inglés. Madrid: Sociedad General Española de Librería.

Fernández de Moya, Zara (2005). Estudio ELE: nivel iniciación. Madrid: Edinumen/Universidad Complutense de Madrid.

Fernández Vargas, Francisca, \& Muñoz Pérez, Julián (2012). Practica tu español. Madrid: Sociedad General Española de Librería.

Fernández, Jesús; Fente, RAFAel, \& Siles, José (1990). Curso intensivo de español: gramática. Madrid: Sociedad General Española de Librería.

Galvín, Isabel; Llanos, Carmen, \& Montemayor, Susana (2006). Proyecto llave maestra. Madrid: Santillana. 
GARCÉs, María Pilar (1997). Las formas verbales en español: valores y usos. Madrid: Verbum.

GARCÉs RodríGuez, Rosario (2004). Vive el español: curso de español: nivel inicial. Barcelona: Edebé.

García Fernández, Nieves, \& Sánchez Lobato, Jesús (1990). Español 2000: nivel inicial (11th. ed.). Madrid: Sociedad General Española de Librería.

García Guerra, Miguel Ángel, \& Rodríguez Martín, José Ramón (2012). Meta ele A2. Madrid: Edelsa.

García-Viño Sánchez, Mónica, \& Ortiz Gómez, María Ángeles (2005). Acento español: nivel intermedio. Madrid: Acento Español.

Gil Toresano, Manuela; Soria, Inés; Duque, Aurora; Espiñeira, Sonia; De la Torre, Nuria, \& VAÑó, Antonio (2009). Agencia ele 2. Madrid: Sociedad General Española de Librería.

Goded, Margarita; Varela, Raquel, \& Hermoso, Ana (2006). Bienvenidos 1. Madrid: EnClaVe-ELE.

González Hermoso, Alfredo, \& Romero Dueñas, Carlos (2004). Eco 1. Madrid: Edelsa.

González Hermoso, Alfredo; Cuenot, Jean-Rémy, \& Sánchez Alfaro, María. (1995). Gramática de español lengua extranjera. Madrid: Edelsa.

González Seara, Carlos (2011). ¡Dale a la gramática! A2. Madrid: EnClave-ele.

González, Marisa; Martín, Felipe; Rodrigo, Conchi, \& Verdía, Elena (2007). Socios 1. Barcelona: Difusión.

Grünewald, Andreas (2006). Aktuelle Spanische Grammatik. Madrid: EnClave-ELE.

Hortelano, María Luisa; Hortelano, Elena G., \& Martínez Requejo, José María (2012). Colega 4. Madrid: Edelsa.

Iglesias Casal, Isabel, \& Prieto Grande, María (2001). ¡A toda página! Madrid: Edinumen

Juan, Olga; De Prado, Marisa, \& Zaragoza, Ana (2002). En equipo.es 1: nivel elemental. Madrid: Edinumen.

Lloret Ivorra, Eva María; Ribas, Rosa; Wiener, Bibiana; Görrissen, Margarita; Häuptle-Barceló, Marianne, \& Pérez Cañizares, Pilar (2011). ¡Nos vemos! A1-A2. Barcelona: Difusión.

López Moreno, Cristina (2010). Un año en España. Madrid: Sociedad General Española de Librería.

Losana, José Emilio (2006). Practica tu español: los tiempos de pasado. Madrid: Sociedad General Española de Librería.

Marcos de la losa, María del Carmen, \& Obra Rodríguez, María del Rosario (1997). Punto final. Madrid: Edelsa. 
Marín, Fernando, \& Morales, Reyes (2014). Vente 1. Madrid: Edelsa.

Marín, Fernando; Morales, Reyes, \& Ibáñez, Andrés (2014). Vente 2. Madrid: Edelsa.

Martín, María Teresa; Pérez, Loreto; Ramos, Javier; Centellas, Aurora; Norris, Dolores, \& Ruiz, JuAna (2007). Español lengua viva 1. Madrid: Santillana/Universidad de Salamanca.

Martín Peris, Ernesto, \& Sans Baulenas, Neus (1997). Gente 1. Barcelona: Difusión.

Martín Peris, Ernesto, \& Sans Baulenas, Neus (2006). Gente 1 (2nd. ed.). Barcelona: Difusión. Martín Peris, Ernesto, \& Sans Baulenas, Neus (2013). Gente hoy 1. Barcelona: Difusión.

Martín Peris, Ernesto; Miquel, Lourdes; Sans Baulenas, Neus, \& Topolevsky Bleger, Marta (1984). Para empezar (A). Madrid: Edelsa.

Martínez, Lola, \& Sabater, María Luisa (2008). Socios 2. Barcelona: Difusión.

Matte Bon, Francisco (1995). Gramática comunicativa del español: de la lengua a la idea (Vol. 1). Madrid: Edelsa.

Miquel, Lourdes, \& Sans Baulenas, Neus (1989). Intercambio 1. Madrid: Difusión.

Miquel, Lourdes, \& Sans Baulenas, Neus (1994). Rápido. Barcelona: Difusión.

Miquel, Lourdes, \& Sans Baulenas, Neus (2002). Rápido, rápido. Barcelona: Difusión.

Moreno, Concha (1991). Curso superior de español. Madrid: Sociedad General Española de Librería.

Moreno, Concha, \& Tuts, Martina (1991). Curso de perfeccionamiento: hablar, escribir y pensar en español. Madrid: Sociedad General Española de Librería.

Moreno, Concha; Hernández, Carmen, \& Miki Kondo, Clara (2007a). Gramática: elemental A1-A2. Madrid: Anaya.

Moreno, Concha; Hernández, Carmen, \& Miki Kondo, Clara (2007b). Gramática: medio B1. Madrid: Anaya.

Moreno, Concha; Moreno, Victoria; \& Zurita, Piedad (2004). Avance: curso de español: nivel elemental. Madrid: Sociedad General Española de Librería.

Moreno, Concha; Moreno, Victoria; \& Zurita, Piedad (2009). Nuevo avance 2. Madrid: Sociedad General Española de Librería.

Moreno, Concha; Moreno, Victoria; \& Zurita, Piedad (2010a). Nuevo avance básico. Madrid: Sociedad General Española de Librería.

Moreno, Concha; Moreno, Victoria; \& Zurita, Piedad (2010b). Nuevo avance 3. Madrid: Sociedad General Española de Librería.

Morley, John, \& Niño, Ana (2009). Basic Spanish grammar for English speakers. Madrid: Santillana. 
Muñoz López, Belén, \& Avendaño, Margarita L. (2005). ¡Fiesta! Nivel 1. Madrid: EnClaVe-ELE.

Oliva, Carmen G., \& Quiñones, María Jesús (2003). Redes: nivel 2. Madrid: Ediciones SM.

Palomino, María Ángeles (2000). Primer plano 1. Madrid: Edelsa.

Palomino, María Ángeles (2001). Primer plano 2. Madrid: Edelsa.

Palomino, María Ángeles (2003). Chicos y chicas: nivel 2. Madrid: Edelsa.

Palomino, María Ángeles (2008). Joven.es. Madrid: Edelsa.

Palomino, María Ángeles (2014). Gramática en diálogo. Madrid: EnClave-Ele.

Pinilla, Raquel (2002). Español más claro: nivel básico. Madrid: Sociedad General Española de Librería.

Pinilla, Raquel, \& San Mateo, Alicia (2008). elexprés. Madrid: Sociedad General Española de Librería.

Prado, Ana (2003). Es tu ritmo: nivel 2. Madrid: Espasa Calpe.

Rodríguez, Beatriz, \& Valencia, María Luz (2005). Clave de sol: nivel 1. Madrid: EnClaVe-ELE.

Rodríguez De la Calle, Santiago (2005). Vive el español: curso de español B1. Barcelona: Edebé.

Rodríguez Martín, José Ramón, \& García Guerra, Miguel Ángel (2012). Meta ele (B1.1). Madrid: Edelsa.

Romero Dueñas, Carlos, \& González Hermoso, Alfredo (2005). Eco 2. Madrid: Edelsa/Universidad Antonio de Nebrija.

Romero Dueñas, Carlos, \& González Hermoso, Alfredo (2008). Competencia gramatical en uso A2: english version. Madrid: Edelsa.

Romero Dueñas, Carlos, \& González Hermoso, Alfredo (2011). Gramática del español lengua extranjera. Madrid: Edelsa.

Ruipérez García, Germán; Aguirre Beltrán, Blanca; García Cabrero, José Carlos, \& Román Mendoza, Esperanza (2002). Primer plano 3. Madrid: Edelsa.

Ruipérez García, Germán; Aguirre Beltrán, Blanca; García Cabrero, José Carlos, \& Román-Mendoza, Esperanza (2003). Primer plano 4. Madrid: Edelsa.

Sánchez, Aquilino; Ríos, Manuel, \& Domínguez, Joaquín (1975). Español en directo: nivel 1B. Madrid: Sociedad General Española de Librería.

Sánchez Lobato, Jesús, \& García Fernández, Enrique (2007a). Nuevo español 2000: nivel elemental (5th. ed.). Madrid: Sociedad General Española de Librería. 
Sánchez Lobato, Jesús, \& García Fernández, Nieves (2007b). Nuevo español 2000: nivel medio (5th. ed.). Madrid: Sociedad General Española de Librería.

Sánchez Lobato, Jesús; Moreno García, Concha, \& Santos Gargallo, Isabel (1997). Español sin fronteras. Madrid: Sociedad General Española de Librería.

Sánchez Lobato, Jesús; Moreno García, Concha, \& Santos Gargallo, Isabel (2005). Nuevo español sin fronteras 1. Madrid: Sociedad General Española de Librería.

SÁnchez Pérez, Aquilino (2006). En directo: nivel medio. Madrid: Sociedad General Española de Librería.

Sánchez Pérez, Aquilino (2007). En directo: nivel elemental. Madrid: Sociedad General Española de Librería.

Sánchez Pérez, Aquilino, \& Sarmiento González, Ramón (2005). Gramática práctica del español actual. Madrid: Sociedad General Española de Librería.

Sans Baulenas, Neus; Martín Peris, Ernesto, \& Garmendia, Agustín (2012). Bitácora 2. Barcelona: Difusión.

Sans Baulenas, Neus; Martín Peris, Ernesto; Garmendia, Agustín, \& Conejo, Emilia (2013). Bitácora 3. Barcelona: Difusión.

Sanz, Fuencisla Isabel, \& Díaz Fernández, Celia (2008). Horizontes. Madrid: Ediciones sm.

SARMiEnto, RAMÓN (2007). Gramática progresiva de español para extranjeros (6th. ed.). Madrid: Sociedad General Española de Librería.

SARmiento, R., \& SÁnchez, Aquilino (1997). Gramática básica del español: norma y uso. Madrid: Sociedad General Española de Librería.

Seijas, Pilar; Tonnelier, Bibiana, \& Troitiño, Sergio (2011). Cuadernos de gramática española: B1. Barcelona: Difusión.

Tano, Marcelo (2009). Expertos. Barcelona: Difusión.

Troitiño, Sergio, \& Seijas, Pilar (2009). Cuadernos de gramática española: A2. Barcelona: Difusión.

Verdía, Elena; González, Marisa; Martín, Felipe; Molina, Inmaculada, \& Rodrigo, ConCHI (2004). En acción 1. Madrid: EnClave-ELE.

Villalba, Félix, \& Hernández, Maite (2005). Español segunda lengua: educación secundaria. Madrid: Anaya. 